\title{
フランス COSI ネットワークによる異世代ホームシェアの運営システム MANAGEMENT SYSTEM ABOUT THE INTERGENERATIONAL HOME SHARE BY COSI-NETWORK IN FRANCE
}

井上早帆，菊地吉信**

\section{Saho INOUE and Yoshinobu KIKUCHI}

\begin{abstract}
The purpose of this paper is to clarify the management system of the Intergenerational Home Share. For that purpose, we focus on the COSI-network, which is the network of groups operating the Intergenerational Home Share programmes in France. The Intergenerational Home Share has been rapidly growing in France in a decade after 2003 and COSI network has been acted an important role. The Intergenerational Home Share in France has various approaches depend on the delivering group's background and relationship to other relevant organisations. Their management systems could be good precedents to Japan.
\end{abstract}

Keywords : Home Share, Management system, Intergenerational, COSI-network, France ホームシェア，運営システム，異世代，COSI ネットワーク，フランス

\section{1. はじめに}

近年、わが国でも大都市圈を中心にシェア居住が広まりつつある。 その中でも家主宅の空き部屋を他人がシェアし、家主と共同生活を 行うシェア居住のことを「ホームシェア」と呼ぶ。海外ではホーム シェアの中でも、高齢者宅の空き部屋を若者がシェアする「異世代 ホームシェア」の取り組みが行われている。欧米諸国でホームシェ アに取り組む団体が加盟するホームシェア・インターナショナルに は、現在 12 力国からの参加がある注1)。今回対象としたフランスで 異世代ホームシェアの運営を行っている団体は 34 団体注2) あり、大 都市から地方中小都市までフランス全土に広がりを見せている。そ のすべての団体が 2003 年以降に創設されたものであり、歴史は浅 いがすでに総計 3,500 組近くの実績がある注 3 )。

フランスでは、住宅困窮者支援事業を実施するアソシアシオン注 4 (association) が近年急速に増加している 1）2）。今回調査した 7 団 体中 6 団体がそのアソシアシオンである。こうした団体を中核とし て行われる異世代ホームシェアでは、高齢者の見守りや生活支援等 の効果に主眼を置きつつ、若者の孤立解消やコミュニケーション能 力の向上、双方への経済的負担の軽減効果等、共同生活による多く のメリットが期待されている3)。

わが国でも、異世代ホームシェアに関心を持つ地域や団体は増え つつあり注5)、アンケート等を通じて一定の関心が持たれていること が示されている 4) 5)。異世代ホームシェアは、住宅費負担の軽減の みならず、孤立を避け精神的な安心感を生み出しうるといった社会 福祉的な面において、わが国における有意義な新しい居住スタイル
の一つとして発展が期待できる。

そこで、本稿では異世代ホームシェアの実績豊富なフランス COSI ネットワークにおける異世代ホームシェアの運営システムを 明らかにし、わが国において異世代ホームシェアを運営するための 資料を提供することを目的とする。そして本稿により得られた知見 を、わが国における異世代ホームシェア普及の一助としたい。

フランスには異世代ホームシェア事業を行っている団体のネット ワークが 3 つある。COSI ネットワーク（Réseau COSI）、

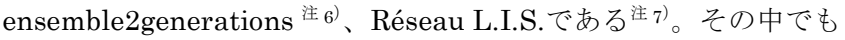
本調査は COSI ネットワークを主たる調查対象とした。別のネット ワークである ensemble2generations はフランチャイズ式であるの に対し、COSI ネットワークは、フランスにおいて異世代ホームシ エアを創始した Le Pari Solidaire を筆頭に、独立した団体同士を対 等の立場として構成しているネットワークである。すべての加盟団 体が異世代ホームシェアの運営という同じ業務を行っているが、そ れぞれの独立性が高く、その団体の所在地が抱える事情に合わせて 運営システムも異なっている。

フランスにおける短期間での広がりと、COSI ネットワークの多 様性は、異世代ホームシェア黎明期にあるわが国の情報源としてよ り適していると考え、今回の調査対象に選定した。

ホームシェアを扱った先行研究としては、園原一代、宮原真美子、 木村直紀による論文や報告 6）7）8）9）等がある。しかし本稿のように フランスにおける運営システムの実態や団体間の比較検討、さらに ネットワークの役割等に注目した研究はない。
* 福井大学工学研究科建築建設工学専攻 博士前期課程

** 福井大学大学院工学研究科 准教授 · 博士 (工学)
Graduate Student, Graduate School, University of Fukui Assoc. Prof., University of Fukui, Dr. Eng. 


\section{2. 調查方法}

\section{2-1 調査概要}

2012 年 10 月、フランスの異世代ホームシェアを行っている団体 の運営担当者にヒアリング調査を行った。ヒアリング項目について 表 1 に示す。今回分析対象とした 6 団体（表 2 、図 1）中 5 団体が 異世代ホームシェアを行うために創設されたアソシアシオンである が、トゥーロンの PACT のみ性格を異にする注 8)。

また、2013 年 5 月に、追加調査をメールにより行った。

表 1 ヒアリング項目について

\begin{tabular}{l||l}
\hline 1.団体について & $\begin{array}{l}\text { (1)創立のきっかけ(2)団体の人数・バックグラウ } \\
\text { ンド(3)役割・担当について }\end{array}$ \\
\hline 2.利用状況について & (1)登録者数(2)マッチング数(3)運営の流れ \\
\hline 3.お金の流れについて & (1)家貨(2)年会費・登録費(3)収支(4改修費注 9) \\
\hline 4. 外部とのつながり & (1)広報について(2)COSI ネットワーク内の位置 \\
& (3)行政とのつながり (4)教育機関とのつながり \\
\hline 5.課題・問題点 & (1)課題・問題点 \\
\hline 6.その他 & (1)その他 \\
\hline
\end{tabular}

表 2 調查対象団体の概要

\begin{tabular}{|c|c|c|}
\hline 団体名 & $\left.\begin{array}{l}\text { 事務所所在地 } \\
\left(\text { 人口注 }{ }^{11}\right)\end{array}\right)$ & ヒアリング対象者 \\
\hline $\begin{array}{l}\text { Le Pari } \\
\text { Solidaire }\end{array}$ & $\begin{array}{l}\text { パリ Paris } \\
\text { ( } 224 \text { 万 } 4 \text { 千人) }\end{array}$ & Aude Messean 氏（代表者） \\
\hline Nante's Renoue & $\begin{array}{l}\text { ナント Nantes } \\
\text { (28万 } 5 千 人)\end{array}$ & Erwan Quenere 氏（代表者） \\
\hline LIEN & $\begin{array}{l}\text { カン Caen } \\
\text { (10万 } 9 \text { 千人) }\end{array}$ & $\begin{array}{l}\text { Caroline Leblanc 氏（異世代 } \\
\text { ホームシェア事業の責任者） }\end{array}$ \\
\hline $\begin{array}{l}\text { At Home } \\
\text { Crochus }\end{array}$ & $\begin{array}{l}\text { オルレアン Orléans } \\
\text { (11万 } 4 千 人)\end{array}$ & $\begin{array}{l}\text { Stéphanie Lumbreras 氏（代 } \\
\text { 表者） }\end{array}$ \\
\hline $\begin{array}{l}\text { Le Parisolidaire } \\
\text { Lyon }\end{array}$ & $\begin{array}{l}\text { リヨン Lyon } \\
\text { (48万 } 4 \text { 千人) }\end{array}$ & Corinne BELOT 氏（代表者） \\
\hline PACT & $\begin{array}{l}\text { トゥーロン Toulon } \\
(16 \text { 万千 千人) }\end{array}$ & $\begin{array}{l}\text { Alain FARACHE 氏（異世代 } \\
\text { ホームシェア事業の責任者） }\end{array}$ \\
\hline $\begin{array}{l}\text { (参考) ensemble- } \\
\text { 2generations }\end{array}$ & $\begin{array}{l}\text { パリ Paris } \\
\text { (224 万 } 4 \text { 千人) }\end{array}$ & $\begin{array}{l}\text { Typhaine de } \\
\text { PENFFNTENYO 氏 (代表者) }\end{array}$ \\
\hline
\end{tabular}

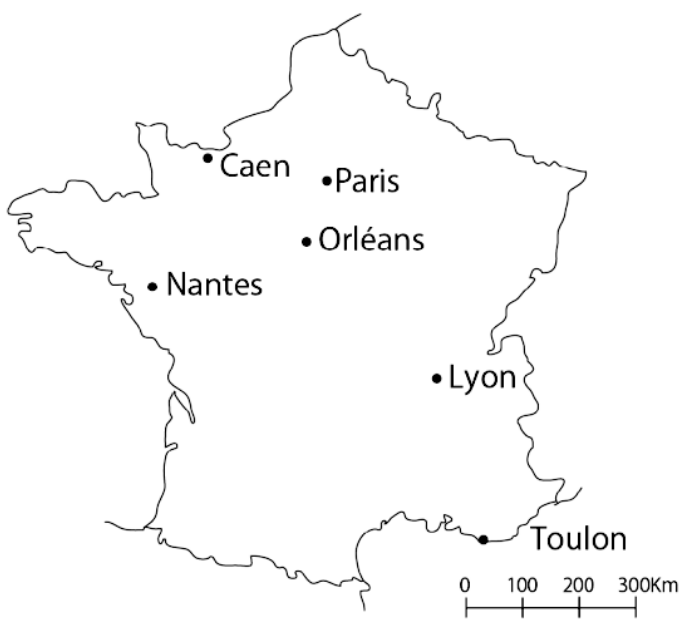

図 1 対象団体の所在地について

\section{2-2 分析方法}

本稿では調查を行った COSI ネットワーク 6 団体の比較検討を行 う。3 章にて調查対象の(1)創立の経緯、(2) COSI ネットワーク概要、 (3)実績、(4)課題と問題点について示し、4 章にてフランス COSI ネ ットワークによる異世代ホームシェアの運営システムにおいて重要 な(1)書類、(2)運用手順、(3)関係主体とのつながり、(4)財源の 4 項目 に焦点を当て分析する。

\section{3. 調査対象について \\ 3-1 各団体の創立の経緯}

フランスにおける異世代ホームシェアの創始者 Aude Messean 氏 (Le Pari Solidaire) は、2003 年のパリの猛暑で多数の高齢者が亡 くなったことをきっかけに、この異世代ホームシェアの活動を起こ そうと考えた。同氏には個人的にも、「高齢者をもっと大切にしなく てはならない」という強い思いがあった。各団体のヒアリング結果 に基づく、各団体の創立のきっかけは主に次の 5 項目にまとめるこ とができる注 12 )。

(1) 2003 年パリの猛暑

（2）アベ・ピエール神父の考え注13）、宗教的考え

（3）高齢者の健康寿命を延ばす、社会とのつながりを広げる

（4）若者の住宅政策、人間性の成長

（5）アルテルナンス注14）利用者のため

\section{3-2 COSI ネットワーク概要}

COSI ネットワークは、Aude Messean 氏（Le Pari Solidaire) のもとへ、自分の地域でも異世代ホームシェアの仕組みを広げたい と相談に訪れた Erwan Quenere 氏 (Nante's Renoue) や、Corinne BELOT 氏（Le Parisolidaire Lyon）らによって創設された。2013 年 4 月時点で、フランス全土の 16 団体が加盟している注 15$)$

COSI ネットワークは、創設当初は情報交流のみであったが、2005 年に正式にアソシアシオンとなった後は、高齢者の健康を守る活動 をしている慈善団体に認知され、COSI ネットワークとして補助金 を受けることができた。その資金で広報に力を入れることができて いる。現在はフランス全土を 4 つのブロックにわけ、それぞれに代 表を置いている。代表の主な役割は活動の相談や新規創立者への援 助等である。COSI ネットワークの役割は主に 4 つある。

（1）共通の憲章の利用 $\cdots$ 表 4 参照

（2）広報活動の援助…加盟団体はパンフレットやホームページの 作成に関して COSI ネットワークからの援助を受けることが できる。また、COSI ネットワークとしての広報も行われてい るので、各団体が知名度を上げる上で役立っている。

（3）新規創立の援助…COSI ネットワークに加盟したい団体への アドバイスを行う。しかし、不当に団体を立ち上げる人々の 加盟を防ぐため、加盟を希望して 1 年経った時点でその団体 が加盟できるか判断される。

（4）活動報告会の開催…年 1 回全団体が集まり、活動報告、意見 交換を行い、互いに高め合っている。新規加盟希望団体の判 断はこの場で行われる。

これら 4 つの役割により、COSI ネットワークはフランス全土に 広がることとなり、フランスにおける異世代ホームシェアの発展に 大きな影響を与えている。今回の調査はその中の 14 団体に連絡を 
取り、調查承諾の返事があった 6 団体（表 2）を対象とした注16）。 3-3 実績

各団体の創立から 2012 年末日までに異世代ホームシェアを行っ た利用者の総数と、2013 年 4 月 1 日時点で異世代ホームシェアを 行っている利用者の人数を表 3 に示す。団体間で利用者数に大きな 差があるが、これは所在地の人口規模や団体の活動年数の違いによ るものと考えられる。また、実際に活動しているスタッフが感じて いる利用者の変化については、以下のような意見が挙げられた。

・多くの高齢者が、最初は他人と暮らすことに抵抗を示すが、実際 に若者と共同生活を行ってみると、一人暮らしのときより生活に 張りがでて、生き生きと暮らしている。(Nante’s Renoue)

・高齢者にとって近くに話し相手がいることは健康寿命を延ばすた めにも重要となっている。(Le Pari Solidaire)

- 若者は留学生も多く、その地域に詳しい高齢者の方とのコミュニ ケーションを通して地域の文化を学ぶことが出来ている。(LIEN)

\section{3-4 各団体が抱える課題と問題点}

各団体が抱える課題と問題点を挙げるならば、主に次の 3 点にま とめられる注 17)。

（1）財源の不安定さ $\cdots$ 活動資金の問題は 6 団体中 4 団体が頭を悩 ませている。非営利の活動ゆえ、人件費を払うためには補助 金が必要不可欠となっている（4-4 節に後述）。その申請作業 の負担が大きいことや、継続的支援が得られるかどうか不確 実なことが運営上のリスクとなっている注 18$) 。$

（2）高齢者の健康状態の見極め…異世代ホームシェア開始時には 問題がなくても、認知症が進行したりその他の病気や死亡と いった問題が生じたりする事態は避けがたく、利用者をごこ で線引きするかの判断は団体スタッフの経験に頼っている。

（3）スタッフの能力…この事業を進めるには、高齢者だけでなく 若者や住宅に関する知識も必要である。COSI ネットワークの 各団体でも、活動者のバックグラウンドによって知識や得意 分野に偏りがあり、他分野の知識を得るために苦労している 人もいた。さらに、有給スタッフは 1 名という団体が多く、 個人の頑張りに依存する部分が大きい注 19)。これは持続性とい う観点からは不安材料である。

\section{4. 異世代ホームシェアの運営システムについて 4-1 必要な書類について}

異世代ホームシェアを行うにあたり、各団体が(1)登録用紙、(2) COSI ネットワーク共通の憲章、(3)団体独自の憲章、(4)ルールのチ エックリストの 4 種類の書類を作成している。各書類の役割につい て表 4 に示す。

COSI ネットワークでは共通して、「助け合いはするが、介護では ない」という立場を高齢者と若者の双方に明確に理解してもらうこ とに特に気を遣っている。そのため、共通の憲章の中に「従属関係 でなく、強制されない気兼ねないものとする」「家族が果たす義務を 全て担うものではない」「相手が一時的に困っているようであれば、 手助けを申し出る」などの考え方を明記している。これにより、高 齢者が若者に介護を強いることを防ぎ、一方で若者に「できるだけ 在宅すること」簡単な手助けをすること」等の意識を高める。また、 利用者がこの憲章を理解した証としてサインしてもらうことで、憲
表 3 各団体の利用者数

\begin{tabular}{|c|c|c|}
\hline 団体名 & 期間 & 利用者数 \\
\hline \multirow[t]{2}{*}{ Nante's Renoue } & 2005 年創立 2012 年末日 & $\begin{array}{l}\text { 高齢者 } 140 \text { 名 } \\
\text { 若 者 } 269 \text { 名 }\end{array}$ \\
\hline & 2013 年 4 月 1 日時点 & $\begin{array}{l}\text { 高齢者 } 40 \text { 名 } \\
\text { 若 者 } 44 \text { 名 }\end{array}$ \\
\hline \multirow[t]{2}{*}{ LIEN } & 2007 年創立 2012 年末日 & $\begin{array}{l}\text { 高齢者 } 108 \text { 名 } \\
\text { 若 者 } 133 \text { 名 }\end{array}$ \\
\hline & 2013 年 4 月 1 日時点 & $\begin{array}{l}\text { 高齢者 } 17 \text { 名 } \\
\text { 若 者 } 20 \text { 名 }\end{array}$ \\
\hline \multirow[t]{2}{*}{ At Home Crochus } & 2009 年創立 2012 年末日 & $\begin{array}{l}\text { 高齢者 } 15 \text { 名 } \\
\text { 若 者 } 12 \text { 名 }\end{array}$ \\
\hline & 2013 年 4 月 1 日時点 & $\begin{array}{l}\text { 高齢者 } 5 \text { 名 } \\
\text { 若 者 } 4 \text { 名 }\end{array}$ \\
\hline \multirow[t]{2}{*}{$\begin{array}{l}\text { Le Parisolidaire } \\
\text { Lyon }\end{array}$} & 2005 年創立～2012 年末日 & $\begin{array}{l}\text { 高齢者 } 190 \text { 名 } \\
\text { 若 者 } 190 \text { 名 }\end{array}$ \\
\hline & 2013 年 4 月 1 日時点 & $\begin{array}{l}\text { 高齢者 } 50 \text { 名 } \\
\text { 若 者 } 50 \text { 名 }\end{array}$ \\
\hline \multirow[t]{2}{*}{ PACT } & 2010 年創立 $\sim 2012$ 年末日 & $\begin{array}{l}\text { 高齢者 } 26 \text { 名 } \\
\text { 若 者 } 26 \text { 名 }\end{array}$ \\
\hline & 2013 年 4 月 1 日時点 & $\begin{array}{l}\text { 高齢者 } 10 \text { 名 } \\
\text { 若 者 } 10 \text { 名 }\end{array}$ \\
\hline \multirow[t]{2}{*}{ Le Pari Solidaire } & 2003 年創立 $\sim 2012$ 年末日 & 約 2,000 組 \\
\hline & 2013 年 4 月 1 日時点 & $\begin{array}{l}\text { 高齢者 } 120 \text { 名 } \\
\text { 若 者 } 170 \text { 名 }\end{array}$ \\
\hline
\end{tabular}

表 4 各書類の役割

\begin{tabular}{l||l}
\hline 登録用紙 & 利用者全員がはじめに作成する書類。主に個人情報 \\
& と、異世代ホームシェアに対する要望等を記載する。 \\
& 運営者が高齢者と若者の組み合わせを考える際にも \\
& 用いるため、利用者は生活スタイルや趣味等について \\
& 細かく答える項目がある。 \\
\hline COSI ネットワ & 異世代ホームシェアの基本的な理念やルール、共同生 \\
ーク共通の憲章 & 活の心得等を記載しており、利用者は内容を理解した \\
& 上で署名する必要がある。COSI ネットワーク内のど \\
\hline 団体独自の憲章 & の団体も同じものを用いている。 \\
\cline { 2 - 2 } & 団体ごとに定めている憲章。団体の運営方針によって \\
& 異なったものとなっている。利用者はこちらの憲章に \\
& も署名する必要がある。 \\
\hline ルールの & マッチングが成立してから行う。それぞれの異世代ホ \\
チェックリスト & 一ムシェアのペアに合わせたルールを作成するため \\
& の指標である。共同生活における詳しいルールを制定 \\
& する。 \\
\hline
\end{tabular}

章に反する行為が認められた場合には団体側が利用者に対して注意 ならびに契約の解除ができるようになっている。

\section{4-2 運用手順}

異世代ホームシェアは、(1)広報、(2)登録、(3)マッチング、(4)ミー ティングの 4 段階を経て開始することができ、実施中に行う(5)アフ ターケアを含めた 5 つの段階に分けることができる。(1)、(2)の段階 は、どの団体も手順としては共通していた（図 2)。しかし、(3)〜(5) の段階では、それぞれの団体で運用手順の違いがみられた注20)。そ の模式図を図 3 に示寸。また、それぞれの段階の一般的な役割につ いて表 5 に示す。

これらの団体による違いは主に 4 つ項目にまとめることができ る（表 6)。また、その 4 項目の特徴について以下に記す。

(1) スタッフのマッチングへの付き添いの有無…ッチングを 2 
者（高齢者・若者）だけで行う団体（2 団体/6 団体）と、3 者 （高齢者・若者・団体スタッフ）で行う団体（4 団体/6 団体） がある。前者は、「 2 人だけの方が相手を良く知ることが出来 る」、後者は「スタッフを交えた方がマッチングをスムースに 進めることができる」との方針で行っている。

（2）マッチングから契約（憲章にサインする）までの期間…マッ チングから契約までの期間にも違いがみられた。マッチング の場で行う（Le Parisolidaire Lyon）団体もあれば、「最低 1 日は空ける」（Nante's Renoue）、「2、3 日後に確認を行う」 (PACT) と、あえて日数を置く団体や、ケースによって変え ている団体もあり、様々であった。あえて日数を置く団体は 「その場の印象や勢いで決めてしまわずに、冷静に考える時 間を置く必要がある」との方針で行っている。

（3）ミーティングのタイミング・手法…ミーティングのタイミン グ・手法は、各団体で大きく異なる。マッチング以降は、ス タッフを含めた 3 者で集まることのない団体 (2 団体/6 団体)、 マッチングとは別の日に、スタッフを含めた 3 者でミーティ ングを行う団体（2団体/6団体）、ケースによって異なる団体 (2 団体/6 団体) がある。
表 5 運用手順の一般的な役割

\begin{tabular}{l||l}
\hline (1)広報 & パンフレットやインターネット、新聞への掲載等注 21 ) \\
\hline (2)登録 & 高齢者: 登録要請を受け次第、スタッフが高齢者宅を \\
& 伺い、要望や必要事項のヒアリング・住宅のチェック \\
& を行う。 \\
& 若者: 登録用紙を記入・提出し、スタッフとの面接を \\
& 行う。 \\
\hline (3)マッチング & 高齢者宅で、顔合わせ、若者による住宅のチェックを \\
\hline (4)ミーティング & 行う。 \\
\hline (5)アフターケア & 憲章への署名、ルール決め等の契約を行う。 \\
\hline
\end{tabular}

\begin{tabular}{|c|c|c|c|c|}
\hline & 高齢者 & \multicolumn{2}{|c|}{ 団体スタッフ } & 若者 \\
\hline (1)広報 & 情報収集 & \multicolumn{2}{|c|}{ 広報活動 } & 情報収集 \\
\hline \multirow{2}{*}{ (2)登録 } & 申請 & & & 申請 \\
\hline & & 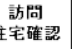 & 面接 & \\
\hline
\end{tabular}

図 2 共通の運用手順

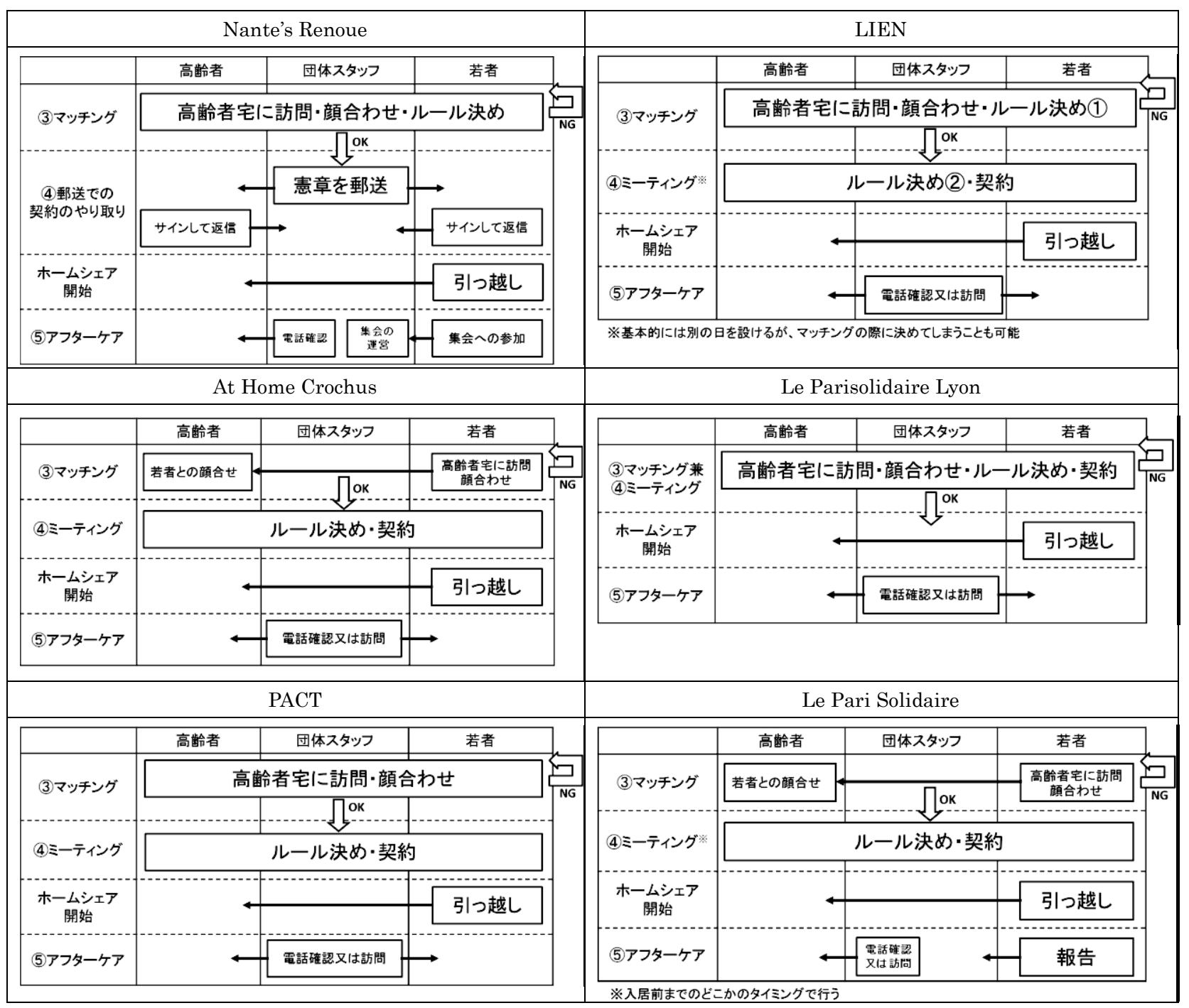

図 3 各団体の運用手順 
表 6 団体間に見られる 4 つの相違点

\begin{tabular}{|c|c|c|c|c|}
\hline 団体名 & $\begin{array}{l}\text { 団体スタッフの } \\
\text { マッチングへの } \\
\text { 付き添いの有無 } \\
\end{array}$ & $\begin{array}{l}\text { マッチングから } \\
\text { 契約までの期間 }\end{array}$ & ミーティングのタイミング・手法 & アフターケアの手段 \\
\hline $\begin{array}{l}\text { Nante's } \\
\text { Renoue }\end{array}$ & 有り & 最低 1 日空ける。 & $\begin{array}{l}\text { ルール決めはマッチングの日に一緒に行う。その後一旦考 } \\
\text { える期間を設けた上で、双方へペア決定の確認を行う。正 } \\
\text { 式に決定された場合、憲章等の書類を郵送で送り、サイン } \\
\text { して返信してもらう。 }\end{array}$ & $\begin{array}{l}\text { 高齢者へは電話での確認（最初の } 2 \text { ケ } \\
\text { 月間、週に } 1 \text { 回）を行う。若者へは、 } \\
\text { 集会（月に } 1 \text { 回）に来てもらい、他の } \\
\text { 利用者と交流しながらの確認を行う。 }\end{array}$ \\
\hline LIEN & 有り & $\begin{array}{l}\text { ケースによって } \\
\text { 異なる。マッチ } \\
\text { ングの場で決め } \\
\text { ることも可能。 }\end{array}$ & $\begin{array}{l}\text { 基本的には、マッチング後にミーティングだけの別の日を } \\
\text { 設けるが、マッチングの日に全て契約まで終わらせること } \\
\text { も可能である。また、別の日を設ける場合でも、マッチン } \\
\text { グの際に基本的なルールは決めてしまうことが多い。 }\end{array}$ & $\begin{array}{l}\text { 電話確認（1 ケ月半に } 1 \text { 回）又は、訪 } \\
\text { 問しての確認（1 年に } 1 \text { 回）を行う。 }\end{array}$ \\
\hline $\begin{array}{l}\text { At Home } \\
\text { Crochus }\end{array}$ & 無し & $\begin{array}{l}1 \text { 日は空くよう } \\
\text { になっている。 }\end{array}$ & $\begin{array}{l}\text { ペア決定後、ミーティングだけの別の日を設けている。(ミ } \\
\text { ーティングはスタッフが立ち会う。) }\end{array}$ & $\begin{array}{l}\text { 電話にて子予定を決めた後に、高齢者宅 } \\
\text { に } 30 \text { 分程度訪問して確認を行う。 } \\
\end{array}$ \\
\hline $\begin{array}{l}\text { Le Parisol- } \\
\text { Idaire } \\
\text { Lyon }\end{array}$ & 有り & $\begin{array}{l}\text { マッチングの場 } \\
\text { で行う。 }\end{array}$ & マッチングの場で契約まで全て終わらせている。 & $\begin{array}{l}\text { 最初の } 1 \text { 年のみ電話確認又は、訪問し } \\
\text { ての確認を行う。最初は毎月行い、慣 } \\
\text { れてきたら } 2 \text { ケに } 1 \text { 回の頻度とする。 } \\
\end{array}$ \\
\hline PACT & 有り & $\begin{array}{l}\text { 2、3 日は空ける } \\
\text { ようにしてい } \\
\text { る。 }\end{array}$ & ペア決定後、ミーティングだけの別の日を設けている。 & $\begin{array}{l}\text { 電話にて予定を決めた後に、高齢者宅 } \\
\text { に訪問して確認を行う。 }\end{array}$ \\
\hline $\begin{array}{l}\text { Le Pari } \\
\text { Solidaire }\end{array}$ & 無し & $\begin{array}{l}\text { ケースによって } \\
\text { 異なる。 }\end{array}$ & 入居前までのどこかのタイミングで行う。 & $\begin{array}{l}\text { 高齢者への確認は、状態に合わせて行 } \\
\text { ったり行わなかったりする。若者には } \\
\text { 毎月 } 1 \text { 回の報告の義務を設けている。 }\end{array}$ \\
\hline
\end{tabular}

（4）アフターケアの手段…アフターケアの手段は、電話確認・訪 問を行う団体（4 団体/6 団体）のほか、高齢者には電話確認、 若者には参加者向けの集会に来てもらい他の利用者と交流し ながら確認する (Nante's Renoue)、高齢者への確認は状態に 合わせて行ったり行わなかったりするが若者には毎月 1 回暮 らしぶりについて報告の義務がある（Le Pari Solidaire）等の 違いが見られる。特に、Nante's Renoue の若者利用者を集め た集会は「若者利用者同士で相談し合うことによって、悩み があっても解決できている」と、効果的である様子がうかが えた。また、At Home Crochus では、契約の際、緊急時に備 えて、若者に対して同居する高齢者の主治医の連絡先を伝え ることを確認している注 22)。

\section{4-3 関係主体とのつながり}

COSI ネットワーク 6 団体の関係主体とのつながりを分析した結 果、(1)利用者、(2)ボランティア、(3)教育機関、(4)援助団体、(5)行政、 (6) COSI ネットワークの $6 つ の$ 主体との連携があった。その一般的 な関係主体とのつながりの模式図を図 4 に示す。また、各団体でス タッフのバックグラウンドや運営方針、団体が所在する地域の特性 等が異なり、関係主体とのつながりも大きく異なる。各団体の関係 主体とのつながりに関する模式図を図 5 に示す。

図に示すように、Nante's Renoue は教育機関とのつながりがない。 その理由は、若者に対しては主にインターネットを通じての広報の みであるが、若者の登録者数は高齢者の登録者数の約 10 倍あり、 教育機関とのつながりの必要性を感じていないからである。

\section{4-4 財源}

各団体の収入の割合について表 7 に示す。 6 団体中 PACT 以外の 5 団体が年会費・登録費の収入だけでは人件費まで賄えず、人件費 を捻出するためには援助団体からの補助金が必要であると考えてい る。(人件費を賄えるだけの年会費・登録費を設定してしまうと、利

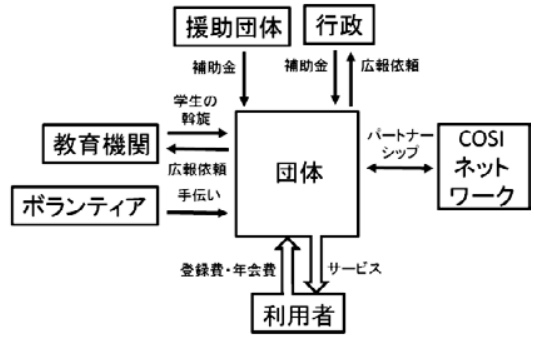

図 4 一般的な関係主体とのつながり

表 7 収入の割合

\begin{tabular}{l|r|r|c}
\hline \multicolumn{1}{c|}{ 団体名 } & 年会費・登録費 & \multicolumn{1}{c|}{ 補助金 } & 計 \\
\hline Nante's Renoue & $52 \%$ & $48 \%$ & $100 \%$ \\
\hline LIEN & $75 \%$ & $25 \%$ & $100 \%$ \\
\hline At Home Crochus & $100 \%$ & 0 & $100 \%$ \\
\hline Le Parisolidaire Lyon & $50 \%$ & $50 \%$ & $100 \%$ \\
\hline PACT & 0 & $100 \%$ & $100 \%$ \\
\hline Le Pari Solidaire & $50 \%$ & $50 \%$ & $100 \%$ \\
\hline \multicolumn{2}{|r|}{} \\
\hline
\end{tabular}

用者の負担が大きくなり過ぎる。）しかし At Home Crochus は援助 団体とのつながりがなく、補助金を受ける体制を築けていない。よ ってこの団体のみ全てのスタッフが無給である。At Home Crochus は、「自分たちの団体はまだ新しく、あまり知られていないので援助 団体とのつながりが作れていない。無給でも活動を続けていれば、 きっと賛同して支援してくれる団体が現れる。」いう考えである。 また、LIENは「同じ額でも、一つの団体から多額の補助金をもら うのでなく、複数の団体から少額ずつ集めるようにしなければ、補 助金を打ち切られた時に活動を続けられない」との考えで、補助金 の申請に多大な労力を注ぎ、積極的に申請を行っている。一方 PACT は、強力なバックアップ体制を築けているため注 23)、利用者から年 会費・登録費を集めずに運営することができている。 
このように、援助団体とのつながりによって、各団体の財源に大 きな違いがみられた注24)

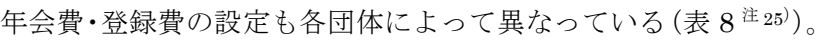
また、多くの団体が家賃にあわせて異なる額の年会費と登録費を設 定している（例えば、家賃無料の若者は家賃有料の若者よりも年会 費が高い等)。家賃については、無料と有料の 2 パターンを設けて いる団体（5 団体/6 団体）と、有料のみの団体（PACT）がある。 PACT にも、無料で良いという高齢者はいるが、「有料で契約を結ん でほしい」という考えのもと、必ず家賃を発生させている。
そして、PACT 以外の団体は、家賃のパターンによって若者の在 宅時間に条件を設けている。基本的にはどの団体も家顀が無料のパ ターンのほうが在宅の条件が厳しく（基本的に夜間は必ず在宅する 等)、有料のほうが緩い（平日の夜間のみ在宅する等）か、もしくは 制約がない。ただし PACT は「決まりごとを作ってしまうとそれ以 外のことをしなくなってしまう」との考えで、交流や手伝いに関す る条件は決めないようにしている。その分、マッチングの際に時間 をかけて双方と話し合い、異世代ホームシェアの目的や考えを理解 してもらうようにしている。

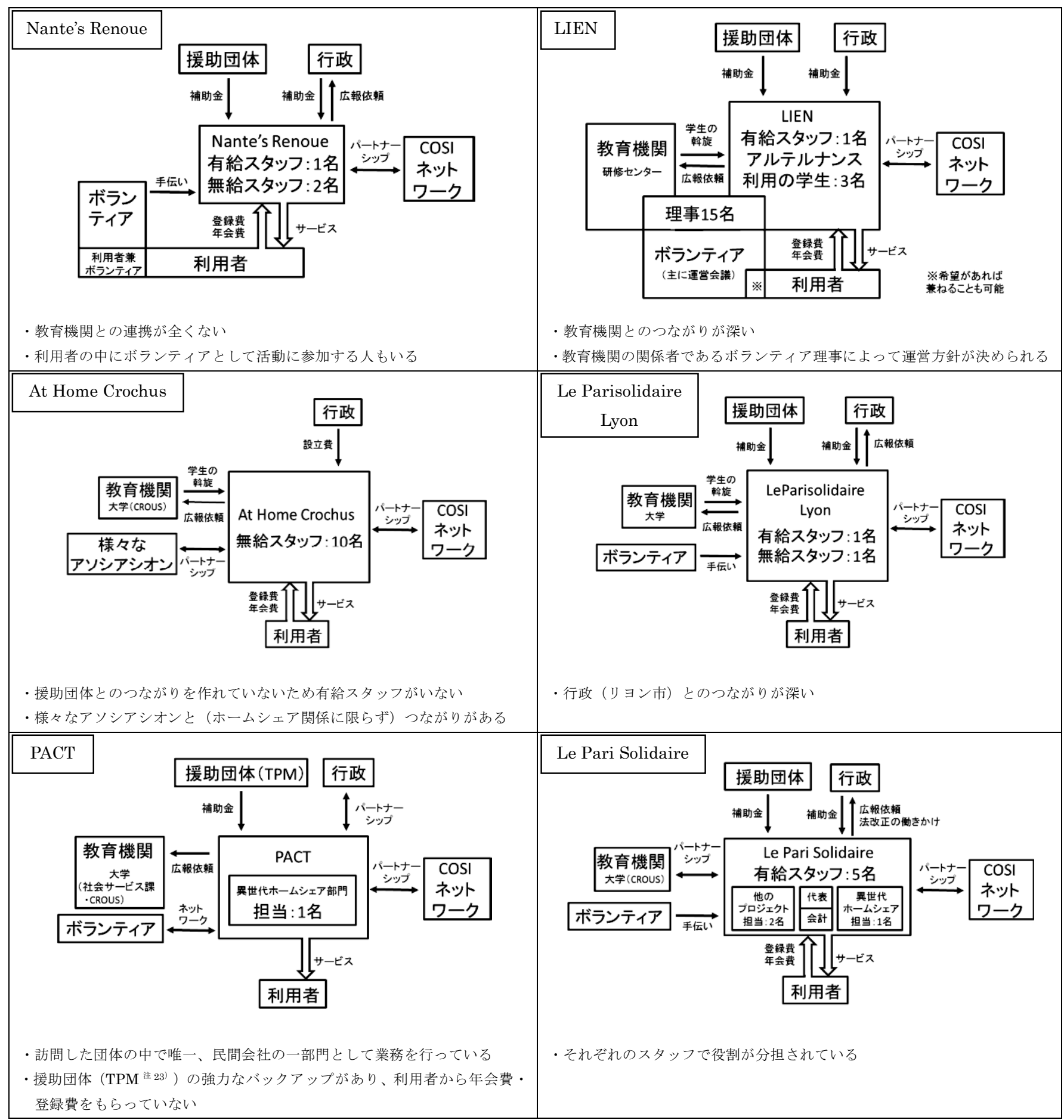

図 5 関係主体とのつながり 
表 8 家賃のタイプと在宅条件・年会費・登録費

\begin{tabular}{|c|c|c|c|c|}
\hline 団体名 & 家賃のタイプ & 若者に課せられる在宅の条件* & 年会費 & 登録費 \\
\hline \multirow[t]{3}{*}{ Nante's Renoue } & 無料 & ·基本的には毎晚在宅する & 高齢者 : $€ 200$ & \multirow{3}{*}{$\begin{array}{l}\text { 高齢者 : } € 30 \\
\text { 若 } \text { 者 : } € 20\end{array}$} \\
\hline & & ・1ヶ月に 2 回の週末は在宅しなくてもかまわない & 若 者: €250 & \\
\hline & 有料（€150まで） & ・平日は基本的に毎晚在宅する & $\begin{array}{l}\text { 高齢者: } € 200 \\
\text { 若 者: } € 200\end{array}$ & \\
\hline \multirow[t]{3}{*}{ LIEN } & $€ 0 \sim 55$ & ・基本的には毎晚在宅する & 高齢者 : $€ 150$ & \multirow{3}{*}{$\begin{array}{l}\text { 高齢者 : } € 30 \\
\text { 若 者 }: € 15\end{array}$} \\
\hline & & ・1ヶ月に1回の週末は在宅しなくてもかまわない & 若 者: €250 & \\
\hline & $€ 55 \sim € 160$ & ・平日は基本的に毎晚在宅する & $\begin{array}{l}\text { 高齢者 : } € 150 \\
\text { 若 者: } € 200 \\
\end{array}$ & \\
\hline \multirow[t]{3}{*}{ At Home Crochus } & 無料 & ・基本的には毎晚在宅する & 高齢者 : $€ 120$ & \multirow{3}{*}{$\begin{array}{l}\text { 高齢者 : } € 30 \\
\text { 若 者 }: € 10\end{array}$} \\
\hline & & ・1ヶ月に 2 回の週末は在宅しなくてもかまわない & 若 者: €210 & \\
\hline & 有料 & ・在宅の条件はない & $\begin{array}{l}\text { 高齢者: } € 160 \\
\text { 若 者: } € 150 \\
\end{array}$ & \\
\hline \multirow{2}{*}{$\begin{array}{l}\text { Le Parisolidaire } \\
\text { Lyon }\end{array}$} & 無料 & ・夜間在宅すること、朝いること等の条件がある & $€ 30$ & \multirow[t]{2}{*}{$€ 20$} \\
\hline & 有料 (€300まで) & ·在宅の条件はない & $€ 30$ & \\
\hline PACT & $€ 30 \sim € 150$ & $\begin{array}{l}\text { •決めないし、明記しないが手伝いはするという立場で考えている } \\
\text { •そのため一つ一つのマッチングを決めるために良く話し合うことを重視している }\end{array}$ & なし & なし \\
\hline \multirow[t]{3}{*}{ Le Pari Solidaire } & 無料 & ・基本的には毎晚在宅する & 高齢者 : $€ 210$ & \multirow{3}{*}{$\begin{array}{l}\text { 高齢者 : } € 30 \\
\text { 若 } \text { 者 : } € 10\end{array}$} \\
\hline & & ・1ヶ月に2回の週末は在宅しなくてもかまわない & 若 者: €350 & \\
\hline & 有料（€500まで） & ·在宅の条件はない & $\begin{array}{l}\text { 高齢者: } € 150 \\
\text { 若 者: } € 200\end{array}$ & \\
\hline
\end{tabular}

*ただし長期休暇の期間はこの限りではない

\section{5. おわりに}

本稿では COSI ネットワーク加盟団体による異世代ホームシェア の運営システムを明らかにした。(1)書類、(2)運営手順、(3)関係主体 とのつながり、(4)財源のそれぞれに共通点と相違点がある。主な共 通点は、憲章の遵守、アフターケアの実施、家賃の段階的設定など、 単なる経済的効果のみではなく高齢者と若者の精神的な支え合いを 促進するための仕組みとなっている点である。一方の相違点は、団 体が所在する都市の背景（家賃が高い地域、アルテルナンス利用者 が多い地域等）に起因するものと考えられる。特に都市規模により 家賃の水準や利用者数も大きく異なっており、やはり人口や大学が 多い大都市注 26) では、利用者数も比例して多くなっている。しかし、 マッチングなどの主要な業務を担当するスタッフ数はどの団体もほ とんど差がなく、それゆえに、大都市の異世代ホームシェアの運営 システムは、中小都市に比べて手順がやや簡略化されている（スタ ッフが利用者と会う回数が少ない、アフターケアにおける若者の方 からの報告を求める等)。

次に、フランスにおける異世代ホームシェアの普及要因について 考えてみると、(1)社会的背景による後押しと、(2)団体同士のネット ワークの 2 つが挙げられる。(1)については、住宅困窮者支援事業を 実施するアソシアシオンが多く、社会的に認知されており制度的に も整っているので、補助金を得られる機会が多く、関係主体とのつ ながりが構築しやすい実情がある。また 2003 年のパリの猛暑が人々 の意識の変革に大きな影響を与えた点も普及要因としては大きい。 また、(2)については、ネットワーク内での運営システムの伝授によ る団体の立ち上げ易さ、広報活動の援助よる資金面・認知度双方一 のサポート、活動報告会での知識の補完等、その影響力は大きい。

ひるがえって現在のわが国では、異世代ホームシェアは黎明期に あり、地域の事情に応じた仕組みを模索している段階であると言え
よう。本稿にて示したフランスの運営システムは、その基本になり うるものとして参考になる点が多い。フランスにおける取り組み同 様、各地域の事情に合わせ応用していくことで、わが国の状況に応 じたより良い運営システムが確立できることを期待したい。

本研究は平成 24 年度国土交通省国土政策関係研究支援事業の支 援を受けた。記して謝意を表す。

\section{参考文献}

1）檜谷美恵子 : フランスの社会住宅政策—ベッソン法の制定とその後の動向 一，都市住宅学 11 号, 1995

2）檜谷美恵子：民間非営利組織アソシェーションの制度的位置づけとその活 動実態一フランスにおける住宅困窮問題への政策対応に関する研究一, 都 市住宅学 35 号, 2001

3) MARIANO SÁNCHEZ, JOSÉ M. GARCÍA, and PILAR DÍAZ : Much More Than Accommodation in Exchange for company-Dimensions of Solidarity in an Intergenerational Homeshare Program in Spain-, Journal of Intergenerational Relationships, 2011

4) NPO ハートウォーミングハウス：高齢世帯所有の部屋ストック有効活用 の可能性ーホームシェアプログラムによる活用提案一, 平成 21 年度長期 優良住宅先導的モデル事業報告書

5）兼平雅俊・杉田良太・新井信幸 : 戸建て住宅の空き家活用方策としての木 一ムシェアの可能性一大学周辺住宅地を対象とした高齢世帯と大学生の マッチング要件の考察一, 日本建築学会大会学術講演梗概集, E-1 分冊, pp1285-1286, 2012

6）宮原真美子・西出和彦: 異世代シェア居住の可能性一USA における高齢者 一若者シェアの事例を通して（1）一，日本建築学会計画系論文集，第 76 巻, 第 661 号, pp513-520, 2011.3

7) 宮原真美子:アメリカにおける非血縁・異世代間シェア居住,住宅, pp14-21, 2010

8）園原一代・木村直紀・奈良明彦 : ホームシェアプログラムによる高齢者世 帯の部屋ストックの活用について〜ホームシェア居住実験を通して〜，住 宅, pp22-28, 2010 
9）木村直紀 : ホームシェアプロジェクトによる高齢者世帯の住宅ストック活 用，建築とまちづくり No.414, pp16-20, 2012

\section{注}

注 1) ホームシェア・インターナショナル（Homeshare International）はホ 一ムシェアの推進を目的として 1999 年に創立された。イギリスのチャリ ティ団体として登録されている（登録番号 1081517）。同団体によれば、現 在、世界でホームシェアが行われている国は、オーストラリア・ニュージ ーランド・ベルギー・カナダ・フランス・ドイツ・オーストリア・アイル ランド・イタリア・スペイン・イギリス・アメリカの 12 ヶ国がある。ホー ムシェア・インターナショナルのホームページ (http://homeshare.org/) 参照。

注 2) ホームシェア・インターナショナルのホームページ (上掲) より（2013 年 4 月時点)。

注 3) 約 3,500 組のマッチング数の内訳は、今回現地で行ったヒアリングに よれば、Le Pari Solidaire : 約 2,000 組、ensemble2generations : 約 1,000 組とパリで活動している団体で約 3,000 組あり、その他の団体で約 500 組 である。異世代ホームシェアは若者（学生）の住宅確保および住宅費負担 軽減という目的も含んではいるが、今回のヒアリングによれば主眼が置か れているのは高齢者の孤立解消である。本研究では、共同生活を通じた異 世代間の交流や支え合いを実現する住まい方の一つとして異世代ホームシ ェアに着目している。

注 4）財団法人自治体国際化協会パリ事務所 :『フランスにおける地域振興と アソシアシオン』, Clair Report No.344，2010.1によれば、アソシアシオ ンとは日本で言う社団法人ないし NPO 法人に近い非営利団体である。

注 5） NPO 法人ハートウォーミングハウスや、株式会社ナウい、NPO 法人 リブ\&リブ、東北工業大学新井研究室等が挙げられる。その他にも大阪や 愛知でも異世代ホームシェアを始めようとしている団体を確認している。

注 6） ensemble2generations は代表の Typhaine de PENFFNTENYO 氏に よって 2005 年に創立された。今回の調査では同氏へのヒアリングも行っ た。同氏によれば、創立のきっかけは、2003 年のパリの猛暑を経験し、高 齢者の意識を変えなければと感じたことと、アベ・ピエールの教えに共感 したことである。COSI ネットワーク同様、フランス全土に活動を展開し ている。フランチャイズ方式で展開しており、同氏が確立したノウハウを 各地域で活動したい人物に伝授していっている。そして、ensemble2generations という名前も統一して用いており、この名前のブランド化を目指し ている。

注 7）ただし Résau L.I.S.は団体のホームページがなく、ホームシェア・イ ンターナショナルにも情報がないため、現在の活動実績が確認できない。 そのため、本論文の記述は 2 つのネットワークに限っている。

注 8）PACT は、住宅·都市開発事業のプランニング、コンサルティング、不 動産管理などを行う民間の会社組織である。その組織の一部門に異世代ホ
ームシェアを実施する部門を設けている。ただし異世代ホームシェア事業 については非営利で行っている。

注 9）ここでいう改修費は、「ホームシェアのために費用をかけて高齢者宅を 改修したか」である。ヒアリングの結果、ほとんどのケースで改修を行っ ておらず、団体側も改修について重要視していないようであった。しかし、 インターネット設備を自己負担するケースはあるとのことであった。

注 10）その他では、高齢者の住宅の条件や、活動を通して感じること、団体 の他の活動などについて質問した。

注 11）都市規模の違いを示すために人口（INSEE : フランス国立統計経済研 究所 2010 年のデータ) を記載している。また、各団体の活動対象地域と その人口、対象年齢、さらに参考のため、その地域の $15 \sim 29$ 歳と 65 歳以 上の人口について付表 1 に示す。

注 12）各団体の創立のきっかけは以下の通りである。

•Nante’s Renoue : 2005年に代表のErwan Quenere氏が創立した。Le Pari Solidaireの活動に共感し、銀行員を辞め、勉強を始め、団体を起こした。 「高齢者には自分の家で出来るだけ長く元気に暮らしてもらいたい」「高 齢者と若者双方の孤立を防ぎ、安心感を与え、他者との関係づくりの力を 伸ばしてもらいたい」という考えがきっかけで活動を始めた。

・LIEN : 2007年創立。創立者は研修センターの関係者で、アルテルナン ス注14) 利用者のためにもパリで始まっていたこの事業が特に必要だと考え たことがきっかけである。アルテルナンス利用者は会社周辺と学校周辺で 部屋を借りるため二重の家賃がかかってしまっていた。LIENの所在地の カルヴァドス県カン市はアルテルナンス利用者が特に多い地区であった。

•At Home Crochus : 2009年に代表のStéphanie Lumbreras氏が創立した。 きっかけは、(1)経済危機による家賃の值上がりが高齢化・孤立、離婚等の 社会問題を深刻化させるため、(2)At Home Crochusのあるオルレアン地域 は広い家が多く、若者が住めるところが少ないため、(3)アルテルナンスを 利用している学生のため、(4)Stéphanie Lumbreras氏は若者の生活援助関 係の仕事に携わっており、「若者が事業に携わることで人間的に成長して もらいたい」という思いがあったための4点である。

・Le Parisolidaire Lyon : 2005年にCorinne BELOT氏が創立した。パリ での活動を知った際に、自分の住んでいる地域（リヨン）も大学町だが家 顀が高くドミトリーが少ないため、若者が住むところを探すのが難しいと いう現状と、高齢者は家にいる時間が長く引きこもりがちとなってしまっ ているという現状を解決できる良い事業だと思ったことがきっかけである。 ・PACT : PACTの礎は、戦後間もなく始まった住宅対策である。1970年 にヴァール県を対象とした会社を確立した。そして、2010年の終わり高齢 者と若者の異世代居住についての事業を始めた。Alain FARACHE氏は、 元々高齢者の住宅改善についての仕事をしていた。初めは界隈に住宅を建 てる研究から始まったが、県と協力しながら個人向けの対策を考えるよう になった。Alain FARACHE氏の一番の目的は高齢者を孤独から守ること である。アベ・ピエール神父の影響も強く受けている。

付表1 各団体の活動対象地域および対象年齢

\begin{tabular}{|c|c|c|c|c|}
\hline 団体名 & 活動対象地域（人口） & 対象年齢 & $\begin{array}{c}\text { (参考) 事務所所在地 } \\
\text { の各人口 }\end{array}$ & $\begin{array}{l}\text { (参考) 活動対象地域 } \\
\text { の各人口 }\end{array}$ \\
\hline $\begin{array}{l}\text { Nante's } \\
\text { Renoue }\end{array}$ & $\begin{array}{l}\text { Nantesとその最寄りの地域（周辺 } 20 \mathrm{~km} \text { 未満） } \\
\text { (不詳、Nantesのみで } 28 \text { 万千人) }\end{array}$ & $\begin{array}{l}\text { 高齢者: } 50 \text { 歳以上*1 } \\
\text { 若 者: } 18 \sim 40 \text { 歳 }\end{array}$ & $\begin{array}{l}65 \text { 歳以上: } 3 \text { 万 } 9 \text { 千人 } \\
15 \sim 29 \text { 歳: } 8 \text { 万 } 3 \text { 千人 }\end{array}$ & $\begin{array}{l}\text { 65歳以上: 不詳 } \\
\text { 15〜29歳: 不詳 }\end{array}$ \\
\hline LIEN & $\begin{array}{l}\text { Basse-Normandie（バス・ノルマンディー地域圈） } \\
\text { (147万 } 3 \text { 千人) }\end{array}$ & $\begin{array}{l}\text { 高齢者: } 55 \text { 歳以上 } \\
\text { 若 者: } 16 \sim 25 \text { 歳 }\end{array}$ & $\begin{array}{l}65 \text { 歳以上: } 1 \text { 万 } 8 \text { 千人 } \\
15 \sim 29 \text { 歳: } 3 \text { 万千 } 5 \text { 人 }\end{array}$ & $\begin{array}{l}\text { 65歳以上: } 28 \text { 万 } 1 \text { 千人 } \\
15 \sim 29 \text { 歳: } 25 \text { 万 } 5 \text { 千人 }\end{array}$ \\
\hline $\begin{array}{l}\text { At Home } \\
\text { Crochus }\end{array}$ & $\begin{array}{l}\text { Communauté d'agglomération Orléans Val de Loire } \\
\text { (オルレアン・ヴァル・ド・ロワール都市圈共同体 }) \\
\text { (27万3千人) }\end{array}$ & $\begin{array}{l}\text { 高齢者：40歳以上 } \\
\text { 若 者：18 30歳 }\end{array}$ & $\begin{array}{l}65 \text { 歳以上: } 1 \text { 万 } 5 千 人 \\
15 \sim 29 \text { 歳: } 3 \text { 万 } 1 \text { 千人 }\end{array}$ & $\begin{array}{l}\text { 65歳以上: } 4 \text { 万人 } \\
15 \sim 29 \text { 歳: } 6 \text { 万人 }\end{array}$ \\
\hline $\begin{array}{l}\text { Le Parisoli- } \\
\text { daire Lyon }\end{array}$ & $\begin{array}{l}\text { Le Grand Lyon（リヨン都市共同体） } \\
\text { (129万 } 3 \text { 千人） } \\
\text { このエリア外でも要求があれば制限しない }\end{array}$ & $\begin{array}{l}\text { 高齢者: } 60 \sim 100 \text { 歳 } \\
\text { 若 者: } 17 \sim 45 \text { 歳 }\end{array}$ & $\begin{array}{l}65 \text { 歳以上: } 6 \text { 万 } 9 \text { 千人 } \\
15 \sim 29 \text { 歳: } 14 \text { 万人 }\end{array}$ & $\begin{array}{l}\text { 65歳以上: } 19 \text { 万 } 5 \text { 千人 } \\
\text { 15〜 } 29 \text { 歳: } 30 \text { 万 } 9 \text { 千人 }\end{array}$ \\
\hline $\mathrm{PACT}$ & $\begin{array}{l}\text { Toulon Provence Méditerranée }{ }^{\text {注23) }} \\
(42 \text { 万千年) }\end{array}$ & $\begin{array}{l}\text { 高齢者: } 60 \text { 歳以上 } \\
\text { 若 者：学生に限る }\end{array}$ & $\begin{array}{l}65 \text { 歳以上: } 3 \text { 万 } 5 千 人 \\
\text { 15〜29歳: } 3 \text { 万人 }\end{array}$ & $\begin{array}{l}\text { 65歳以上: } 9 \text { 万 } 4 \text { 千人 } \\
\text { 15 29歳: } 7 \text { 万 } 4 \text { 千人 }\end{array}$ \\
\hline
\end{tabular}

*1障がい者も含まれる 
・Le Pari Solidaire : 2003年に代表のAude Messean氏が知人と2人で創立 した。創立のきっかけは 2003 年のパリの猛暑で、一人暮らしの高齢者が大 勢亡くなった際に、高齢者をもっと尊敬し、大切にしなければならないと 考えたからである。その他にも「高齢者をもっと敬わなければならない」 という宗教的考えもあった。

注 13）アベ・ピエール, 田中千春（訳）:『遺言…苦しむ人とともに』, 人文 書院, 1995.4 によれば、アベ・ピエール(Abbé Pierre)は聖職者であり、元 フランス国民議会議員でもある。ホームレス等の救済活動に一生涯を費や した。エマユス共同体という、共同生活をしながらリサイクル活動による 自活の実現を目指寸活動を行う共同体の創設者でもある。

注14）アルテルナンス（alternance）は学生向けの就労体験の制度である。 フランスでも若者の就職難が深刻化している中で、卒業時に実地経験があ り、即戦力となる学生を創り出そうという目的から国によって設置された。 様々な形態があり、たとえば 3 週間通学して次の 2 週間は通勤するというよ うな形で通勤と通学を両立させる。相手先企業は受け入れてくれるところ ならどこでもよく、学生は自分が行きたい企業があれば自ら依頼し、許可 が出れば利用することができる。コクボコミュニケーションのホームペー ジ (http://www.kokuboco.net/Pages/universityandgrandecole.aspx) 参照。 注 15）登録は 16 団体（2012 年 9 月時点）だが、現地でヒアリングしたとこ ろ実際には活動停止中の団体も含まれている。COSI ネットワークのホー ムページ (http://www.reseau-cosi.com/) 参照。

注16）16団体のうち，遠隔地ゆえに現地訪問が困難と判断した 2 団体を除く 14 団体に連絡をとった。そして 14 団体中、今回調査した 6 団体以外は返事 がなく、具体的な活動を確認できなかった。

注17）課題と問題点について

・財源の不安定さ : 補助金を得て有給スタッフを雇えるようになりたい。 (At Home Crochus) /資金集めが一番大変で時間がかかっている。 (LIEN) / 補助金を増やし、他の有給スタッフを雇い、事業の拡大をし たい。(Le Parisolidaire Lyon) /補助金を打ち切られたら活動できなくな ってしまう。(Le Pari Solidaire)

・高齢者の健康状態の見極め：世話をしてもらうという考えは絶刘にあっ てはいけないので特に気をつけている。（Nante's Renoue）／高齢者の認 知症や死亡の問題を抱えている。(Le Pari Solidaire) /䋗傾向が強い高齢 者に苦労をしている。(ensemble2generations)

・スタッフの能力 : 福祉関係の知識に苦労している。(PACT)

注18）財団法人自治体国際化協会パリ事務所 :『フランスにおける地域振興と

アソシアシオン』, Clair Report No.344, 2010.1によれば、この問題はCOSI

ネットワークの団体だけでなく、フランスのアソシアシオンに共通して言 える問題である。

注19）各団体のスタッフ数と業務の実情について以下の表に示す。

\begin{tabular}{|c|c|c|}
\hline 団体名 & スタッフ数 & 業務の実情 \\
\hline $\begin{array}{l}\text { Nante's } \\
\text { Renoue }\end{array}$ & $\begin{array}{l}\text { 有給スタッフ: } 1 \text { 名 } \\
\text { 無給スタッフ : } 2 \text { 名 }\end{array}$ & $\begin{array}{l}\text { 実質的に全ての業務を有給スタッ } \\
\text { フ1人でこなしている。 }\end{array}$ \\
\hline LIEN & $\begin{array}{l}\text { 有給スタッフ : 1名 } \\
\text { アルテルナンス利用の } \\
\text { 学生 : } 3 \text { 名 }\end{array}$ & $\begin{array}{l}\text { 学生に事務作業を補助してもらっ } \\
\text { てはいるが、ほとんどの業務を有 } \\
\text { 給スタッフ } 1 \text { 人で行っている。 }\end{array}$ \\
\hline $\begin{array}{l}\text { At Home } \\
\text { Crochus }\end{array}$ & 無給スタッフ：10名 & $\begin{array}{l}\text { 2名のスタッフが中心となり、ほと } \\
\text { んどの方が現役で他の仕事に勤め } \\
\text { ながら活動に携わっている。 }\end{array}$ \\
\hline $\begin{array}{l}\text { Le Parisol- } \\
\text { idaire } \\
\text { Lyon }\end{array}$ & $\begin{array}{l}\text { 有給スタッフ : 1名 } \\
\text { 無給スタッフ: } 1 \text { 名 }\end{array}$ & $\begin{array}{l}\text { 実質的に全ての業務を有給スタッ } \\
\text { フ1人でこなしている。 }\end{array}$ \\
\hline PACT & この事業の担当者: 1 名 & $\begin{array}{l}\text { 実質的に全ての業務を担当の方の } \\
\text { みでこなしている。 }\end{array}$ \\
\hline $\begin{array}{l}\text { Le Pari } \\
\text { Solidaire }\end{array}$ & $\begin{array}{l}\text { 有給スタッフ : } 5 \text { 名 } \\
\text { (内、他のプロジェク } \\
\text { 卜担当 } 2 \text { 名、会計1名) }\end{array}$ & $\begin{array}{l}\text { 異世代ホームシェア事業の運用は } \\
\text { 担当の方 } 1 \text { 人で行っている。しかし } \\
\text { 会計や広報活動等は他のスタッフ } \\
\text { と分担している。 }\end{array}$ \\
\hline
\end{tabular}

注20) 各団体の運用手順における手間の合理化については以下の通りである。 ・Nante's Renoue : マッチングとミーティングを同じ日に行うことで手順 を簡略化しつつも、その場で契約までを終わらすことを避けるため、契約
は1日以上冷静に考える時間を経た後、郵便で行っている。また、アフター ケアに力を入れており、月に1回、若者の利用者のための集会を催している。 · LIEN : ミーティングのタイミングや回数は参加者の状態に合わせて臨 機応変に設定している。

・At Home Crochus : マッチングは、「2人だけで話し合ったほうがお互い をよく知ることができる」との考えの元、あえてスタッフの付き添い無し で行っている。その後、別の日に高齢者と若者とスタッフ (必ず 2 名で参加 するようにしている) でミーティングを行うという手順を採っている。

・Le Parisolidaire Lyon：マッチングの日に全て終わらせることで手間が 最小限となっている。マッチングの是非について考える時間は有していな い。

・PACT : マッチングを3者で行った後に、別の日に3者で再び集まりミー ティングを行っている。若者に在宅の条件を課さないためにも、手間暇か けてしっかり話し合うようにしている。

・Le Pari Solidaire : ミーティングのタイミングはケースに合わせて臨機 応変に対応している。アフターケアの手間を最小限に抑えるため、若者か らの報告を義務付けている。

注21）有効な広報手段について、若者はインターネット、高齢者は新聞や口 コミ、各種広報誌への掲載との意見が多かった。また、イベントで活動の 周知を行っている団体 (Nante's Renoue、At Home Crochus) や、福祉関 係のアソシアシオンの会合に参加し広報させてもらっている団体（At Home Crochus）もある。その他にもCOSIネットワークによる広報活動の 援助（3-2節参照）や行政や教育機関への広報依頼（4-3節参照）等がみら れる。

注22） ensemble2generationsでは原則としてアフターケアを行っておらず、 マッチングが成立した時点で活動が終了する。アフターケアを行っている 点は、COSIネットワークによる異世代ホームシェアがより社会福祉的な目 的によるものであることを示す一端である。

注23）PACTは、TPM によって強力なバックアップを受けている。TPMと は「Toulon Provence Méditerranée=トゥーロン プロヴァンス 地中海」 の頭文字から名付けられた 12 の共同体の管轄区で活動する都市機構である。 都市やコミュニティの問題を中心に様々な活動をしている。TPMのホーム ページ (http://www.tpm-agglo.fr/) 参照。

注24）各団体が補助金の援助を受けている機関は以下の通りである。

· Nante's Renoue : Fonds social européen（欧州社会基金）：職業訓練や 雇用創出施策のための資金を提供している／PAYS DE LA LOIRE（ペイ・ ド・ラ・ロワール地域圈）: 行政/LOIRE ATLANTIQUE（ロワール・ア トランティック県) : 行政/FONDATION SNCF（SNCF財団）：若者を支 援する団体/Nantes（ナント市）：行政/Crédit Mutuel（フランス相互信 用連合銀行） / cress : 社会連帯経済の地域組合 $/$ malakoff mederic : 社会 福祉団体

・ LIEN : Ministère de l'Éducation nationale（国民教育省）：フランス の省の一つで教育行政を担当している／Basse-Normandie（バス・ノルマ ンディー地域圏) : 行政/LA MANCHE conseil général : マンシュ県の県 議会 /L' ORNE conseil général : オルヌ県の県議会/Calvados conseil général : カルヴァドス県の県議会 $/ \mathrm{CAEN}$ (カン市) : 行政/Carsat : 社 会保障の公共サービスを行う民間団体 $/ \mathrm{MSA}$ （農業社会共済）：農業の社 会サービス組織/Vauban Humanis：社会福祉団体

- Le Parisolidaire Lyon : Crédit Mutuel（フランス相互信用連合銀行）

/CARSAT : 社会保障の公共サービスを行う民間団体／Villeurbanne Est Habitat：社会住宅の管理などを行う民間団体/Répam santé : 保険会社 /AG2R : 保険会社/VILLE DE LYON (リヨン市) : 行政/FONDATION DE FRANCE（フランス財団）：日本における共同募金に近い団体

- PACT : TPM 注 23 )

- Le Pari Solidaire : MAIREI DE PARIS (パリ市) : 行政/Île-de-France (イル・ド・フランス地域圈) : 行政 /L'Assurance retraite Île-de-France : 社会保障の公共サービスを行う民間団体／SGIM : 社会住宅の管理などを 行う民間団体／Paris Habitat：社会住宅の管理などを行う公共機関／ FONDATION SNCF（SNCF 財団）：若者を支援する団体／FONDATION DE FRANCE（フランス財団）/Fonds social européen（欧州社会基金） /France Bénévolat : フランスのボランティア団体／Université Pierre-et -Marie-Curie : ピエール・マリー・キュリー大学/Val-de-Marne conseil 
général：ヴァル・ド・マルヌ県の県議会／Ministère de l'Éducation nationale（国民教育省）：フランスの省の一つで教育行政を担当している

/Essonne conseil général: エソンヌ県の県議会/Vélizy-Villacoublay (ヴ ェリジーヴィラクブレー市) : 行政/Yvelines conseil général : イヴリーヌ 一県の県議会/droit de cité habitat action logement : 社会住宅の管理な どを行う民間団体／TOIT ET JOIE : 社会住宅の管理などを行う民間団体 注 $25 ）$ 訪問時（2012年10月）のユーロの相場は1ユーロ $=102.5$ 円である。

注26）参考までに事務所所在地の大学数と利用者数を右表に示す。この大学 数は、公立と私立の双方を含む一般的な大学のみの数である。国民教育省 のホームページ (http://www.education.gouv.fr/) 参照。

\begin{tabular}{l||c|l}
\hline \multicolumn{1}{|c|}{ 団体名 } & $\begin{array}{c}\text { 事務所所在地 } \\
\text { の大学数 }\end{array}$ & \multicolumn{1}{|c}{$\begin{array}{c}\text { 2013年4月1日時点の } \\
\text { 利用者数 }\end{array}$} \\
\hline Nante's Renoue & 31 & 高齢者40名, 若者44名 \\
\hline LIEN & 16 & 高齢者17名, 若者 20 名 \\
\hline At Home Crochus & 12 & 高齢者5名, 若者4名 \\
\hline Le Parisolidaire Lyon & 48 & 高齢者50名, 若者50名 \\
\hline PACT & 14 & 高齢者10名, 若者10名 \\
\hline Le Pari Solidaire & 177 & 高齢者120名, 若者 170 名 \\
\hline
\end{tabular}

(2013年 6 月 10 日原稿受理，2014年 5 月 23 日採用決定） 